\section{Basic science still to grow, but less quickly}

Washington

SCIENCE has emerged largely unscathed in President Reagan's proposed budget for fiscal year 1986. Although once again the major increases have been reserved for military research and development (see below), the federal programmes that support the bulk of scientific research, particulariy basic research at universities, seem to have been granted a special dispensation from the draconian measures applied elsewhere in the non-military portions of the budget.

The large increases slated for the Department of Defense and the administration's refusal to consider a tax increase made it a foregone conclusion that this year's budget would not embody much improvement in the record federal deficit. The 1986 deficit is projected of ficially at $\$ 180,000$ million; even by 1988 , the last year of Reagan's term, the deficit will be down only to $\$ 144,000$ million.

This is in spite of a series of severe costcutting measures: a 5 per cent pay cut for all federal civilian employees; a cut-off of government-subsidized student loans to families earning more than $\$ 32,500$ a year,

\section{Losers for 1986}

\section{Washington}

THE major losers in this year's science budget are not the major grant-making agencies. The Sea Grant programme of the National Oceanic and Atmospheric Administration (NOAA), disliked by science adviser George Keyworth, is due for elimination. NOAA's Great Lakes Environmental Laboratory would be shut down, as would the undersea research programme and the Coastal Zone Management grants. The National Bureau of Standards (NBS), like NOAA a part of tr: Department of Commerce, is alsu earmarked for cuts. The administration will try once again to terminate NBS's fire research and building research programmes; NBS would lose about \$17 million in operating funds overall, out of roughly $\$ 120$ million. Overall, the Commerce Department research and development budget is to fall by $\mathbf{\$ 1 1 0}$ million, to $\$ 271$ million.

The US Geological Survey, part of the Department of the Interior, is due for a 2 per cent cut, to $\$ 588$ million in total obligations. Other losers are the Department of Transportation, the Veterans Administrations and the Nuclear Regulatory Commission all of which face cuts of a few per cent in various small research programmes.

Stephen Budiansky federal employees. another. projects already under way.

\section{National Science Foundation}

a cut-off for student grants at $\$ 25,000$ a year and a provision that no student can receive more than $\$ 4,000$ a year from public sources, loans or other subventions; a freeze on payments to physicians and hospitals under Medicare (which covers those eligible for social security retirement or disability payments) and a freeze on the number of persons covered by Medicaid (which is for those eligible for welfare payments); and a freeze on pensions for

As always, the final shape of the budget for the financial year beginning on 1 October 1985 , will be determined only after the details have been scrutinized by the responsible congressional committees and after Congress as a whole has had its say on the issues raised by the budget. The proposed cutbacks in social programmes and the increase of defence spending will be two major issues, the size of the deficit

Science has, however, taken its medicine (see below). While federal research and development is to increase by 12 per cent overall, the non-defence portion of that is actually due for a 4 per cent cut. Basic research is to receive a 1 per cent overall increase, behind the inflation rate. But researchers who rely upon the major federal grant-givers, the National Science Foundation (NSF) and the National Institutes of Health (NIH), have little to worry about. The 4 per cent cut is coming out of the technology-development programmes that the Reagan administration has never liked. And while there are to be no new construction projects beginning in 1986 , neither will there be any cancellations of

After two years of healthy increases in the NSF budget, this year's single-digit growth of 7 per cent may seem small. But that is still well ahead of inflation. NSF's engineering programme will receive the greatest percentage gain, 13 per cent; the founda-

US research and development budget ( $\$$ million)

\begin{tabular}{lccc}
\hline & 1984 & 1985 & 1986 \\
Defence-related & actual & estimated & $\begin{array}{c}198 \text { proposed } \\
\text { Health and Human Services }\end{array}$ \\
(NIH) & 4,408 & 32,318 & 39,426 \\
Energy & $(4,252)$ & 5,472 & 5,159 \\
NASA & 4,642 & $(4,835)$ & $(4,561)$ \\
NSF & 2,877 & 4,805 & 4,712 \\
Agriculture & 1,203 & 3,506 & 3,730 \\
EPA & 868 & 1,354 & 1,447 \\
All others & 261 & 940 & 882 \\
R\&D facilities & 2,104 & 312 & 327 \\
Total & 1,853 & 2,248 & 1,915 \\
& 45,052 & 53,237 & 2,075 \\
\end{tabular}

tions's new engineer director, Erich Bloch, is pushing to expand the Engineering Research Centers programme at universities.

Mathematical and physical sciences are slated for an 8 per cent increase, as are biological sciences; earth sciences would get a 6 per cent rise. After initially resisting congressional enthusiasm and a National Science Board recommendation, the administration this year is proposing a major programme not only to improve access to supercomputers but actually to purchase machines and create supercomputer centres around the country at a cost of $\$ 46$ million.

Science education, which, along with all federal education programmes had been on the administration's hit-list until the

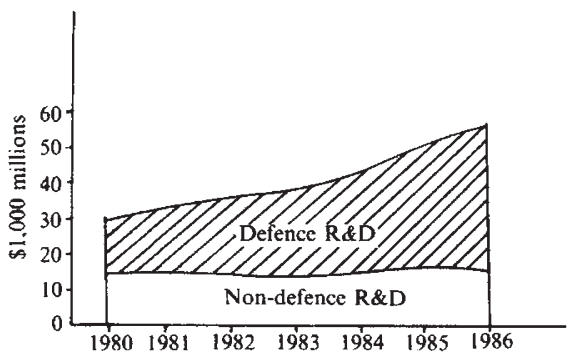

The growth in defence research and development during the Reagan years.

deteriorating state of the nation's schools became a campaign issue for President Reagan, will remain at the present level of $\$ 83$ million. Graduate fellowships will also remain at the present level ( $\$ 27$ million within that total).

National Institutes of Health

Word leaked out last month about the administration's plans for dealing with the ever-expanding $\mathrm{NIH}$ budget, so there are no surprises in the official budget. Congress invariably tries to one-up the administration when it comes to NIH support; last year, Congress voted to give NIH extra money to increase new research grants each year from 5,000 to 6,500 .

The administration, determined to hold the line, has ordered NIH to award only 5,000 this year, disposing of the excess funds by committing them to the future years of a portion of the three-year grants awarded now. The 5,000-grant limit would remain for 1986 . The move would prevent annual increases of about $\$ 300$ million in 